SJ Quinney College of Law, University of Utah Utah Law Digital Commons

Utah Law Faculty Scholarship

Utah Law Scholarship

$11-2018$

\title{
From Foundational Law to Limiting Principles in Federal Indian Law
}

\author{
Alexander Tallchief Skibine \\ University of Utah, SJ Quinney College of Law, alex.skibine@law.utah.edu
}

Follow this and additional works at: https://dc.law.utah.edu/scholarship

Part of the Indian and Aboriginal Law Commons

\section{Recommended Citation}

Skibine, Alexander Tallchief, "From Foundational Law to Limiting Principles in Federal Indian Law" (2018). Utah Law Faculty Scholarship. 135.

https://dc.law.utah.edu/scholarship/135 


\title{
FROM FOUNDATIONAL LAW TO LIMITING PRINCIPLES IN FEDERAL INDIAN LAW.
}

\author{
Alex Tallchief Skibine*
}

\section{INTRODUCTION}

In a noted article, the late Philip Frickey described how federal Indian law, since its inception, has been "exceptional" in the sense of being distinctive compared to other areas of American Public Law. ${ }^{1}$ The foundational principle animating this exceptionalism is Chief Justice Marshall's description of Indian nations as Domestic Dependent Nations that, although existing within the territorial boundaries of the United States, have retained many aspects of their original sovereignty. ${ }^{2}$ Professor Frickey, however, also described how more recently Federal Indian Law's exceptionalism was being dismantled by what he called a "flattening of federal Indian law into American Public law by importing general constitutional and subconstitutional values into the field." ${ }^{3}$ In my view, one of the main reason for the Court's failure to stand by the Exceptionalism of the past is that the political, economic, and social position of tribes within the United States has dramatically changed since these exceptional principles were initially developed. From conquered nations restricted to isolated reservations with a poor understanding of American society, Indian nations are now part of the economic and political life to the United States. Most reservations are no longer isolated or inhabited only by Indians, and tribal leaders have acquired a sophisticated understanding of the United States legal and political system. It is, therefore, not surprising that law is trying to catch up with these new realities.

Although this can explain why federal Indian law's exceptionalism is changing, it does not explain why it is changing in the particular way that it is. In this Article, I am

\footnotetext{
${ }^{*}$ S.J. Quinney Professor of Law, University of Utah S.J. Quinney College of Law. Thanks to the Editors of the Montana Law Review for organizing a great symposium. This research was made possible, in part, through a generous grant from the Albert and Elaine Borchard Fund for Faculty excellence.

${ }^{1}$ See Philip P. Frickey, Native American Exceptionalism in American Public Law, 119 Harv. L. Rev. 431 (2005).

${ }^{2}$ From this principle, the Court has derived three other principal doctrines: the congressional plenary Power doctrine giving Congress exclusive and plenary authority over Indian Affairs, the Indian trust doctrine under which the United States has a duty of protection towards the tribes, and the Indian Preemption doctrine that presumes that states do not have jurisdiction over Indians in Indian Country. From the Indian sovereignty doctrine, the Court derived one important sub doctrine, the tribal sovereign immunity doctrine. From the congressional plenary power doctrine, the Court derived the Mancari subdoctrine, allowing Congress to single out Indians for special treatment without such classification being considered a racial classification. Finally, from the trust doctrine, the Court derived the Indian canons of statutory and treaty interpretations.

${ }^{3}$ See Philip P. Frickey, A Common Law for our Age of Colonialism: The Judicial Divestiture of Indian tribal Authority over Non-Members, 109 Yale L. J. 1, 7. According to Professor Frickey, this "flattening" has been accomplished by the Court in essentially four ways: First, abandoning the Indian law canons of statutory construction. Second, using Federal common law under the guise of statutory interpretation. Third, using constitutional values as a premise for its common law even though the constitution is not strictly speaking applied to Indian tribes. Fourth, importing principles from the general law to harmonize its federal common law decisions with general notions of federal law.
} 
arguing that one of the reason animating the Court's move away from Justice Marshall's exceptionalism is its fear that under traditional foundational principles of federal Indian law, ${ }^{4}$ Indian tribes may gain what the court subjectively perceives to be "unfair" advantages over non-Indians. Therefore, the Court has been looking for limiting principles tending to achieve level playing fields between tribal and non-tribal actors. ${ }^{5}$ This Article also argues, however, that while looking for a level playing field may sound like a worthwhile goal, there are many pitfalls involved in this process that may end up hurting tribal sovereign interests.

I realize that describing the Court as looking for a "level playing field" may sound too generous to some and it is true that at times, the Court's jurisprudence seems animated by unfounded and irrational fears about Indian nations. One area where fear of an unlevelled playing field has made the Court overreact has been in the area of tribal jurisdiction over non-members. The foundational principle here was that although Indian tribes could no longer be considered foreign nations capable of having independent relations with other foreign nations, they still retained all their original inherent sovereign powers unless such powers had be taken away by Acts of Congress or given up in treaties entered with the United States. ${ }^{6}$ However, in 1981, the Court came up with a limiting principle according to which Indian tribes could only exercise those inherent sovereign powers that were "necessary" to tribal self-government. ${ }^{7}$ While some pro tribal attorneys at the time expressed the belief that they could work around this limiting principle, the Supreme Court has, in the great majority of cases, refused to uphold tribal jurisdiction over non-members. ${ }^{8}$

Because that subject has been already much discussed by a number of scholars, ${ }^{9}$ this article will analyze other areas of Federal Indian law where the application of exceptionalism and foundational principles is especially likely to motivate the Court to search for limiting principles in the near future. Thus, Part II will focus on Tribal sovereign immunity cases and Part III will analyze tribal state conflicts involving

\footnotetext{
${ }^{4}$ On foundational principles of federal Indian law, see David H. Getches, Conquering the Cultural Frontier: The New Subjectivism of the Supreme Court in Indian Law, 84 Cal L. Rev. 1573 (1996).

${ }^{5}$ In previous writings, I have argued that the Court was conscious that the tribes were being incorporated as the third Sovereign into our federalism but was also aware that Congress was either unwilling or incapable of adjusting the parameters governing this incorporation. To counter this perceived Congressional paralysis, the Court assumed the lead in defining the terms of this tribal incorporation. See Alexander Tallchief Skibine, The Supreme Court's Last 30 years of Federal Indian Law: Looking for Equilibrium or Supremacy? 8 Colum. J. Race \& L. 277 (2018).

${ }^{6}$ See Felix Cohen Handbook of Federal Indian Law 2012 Ed, pp. 206-211.

${ }^{7}$ See Montana v. United States, 450 U.S. 544 (1981). Three years earlier, the Court had also held that Indian tribes did not have the inherent sovereign power to prosecute non-tribal members. See Oliphant $v$. Suquamish Indian Tribe, 435 U.S. 191 (1978).

${ }^{8}$ See Skibine, Supreme Court's last 30 Years, supra at note 5.

${ }^{9}$ The leading article is probably Philip Frickey, Our Age of Colonialism, supra at note 3. See also Matthew L.M. Fletcher, The Supreme Court and Federal Indian Policy, 85 Neb. L. Rev. 121 (2006), and Alex Tallchief Skibine, Constitutionalism, Federal Common Law, and The Inherent Powers of Indian Tribes, 39 Am. Ind. L. Rev. 77, 83-99 (2014-2015).
} 
off-reservation treaty rights. ${ }^{10}$ Finally, Part IV focuses on state taxing power within Indian reservations. Not only is the judicial search for a level playing field evident in these cases but the evolution of the law in this area should serve as a cautionary tale for the areas of law covered in Parts II and III. Thus, what started out as a search for a fair solution between conflicting tribal and state taxing interests ended up being used to promote state sovereign interests to the detriment of tribal sovereign and economic interests.

\section{PART II: The level playing field principle in tribal sovereign immunity cases.}

Foundational principle: As stated by the Supreme Court, tribal sovereign immunity "is a necessary corollary to Indian sovereignty and self-governance." ${ }^{11}$ Furthermore, only Congress, pursuant to its plenary power, can abrogate tribal sovereign immunity. ${ }^{12}$ However, as recently stated by the Court, another governing principle concerning congressional abrogation of tribal sovereign immunity is that "such a congressional decision must be clear. The baseline position, we have often held, is tribal immunity; and "[t]o abrogate [such] immunity, Congress must 'unequivocally' express that purpose." 13

\section{Level Playing Field and Tribal Sovereign Immunity in Indian Gaming.}

Unlike other attributes of tribal sovereignty, notably inherent tribal jurisdiction over non-members, tribal sovereign immunity has, for the most part, remained unscathed from Supreme Court attacks. ${ }^{14}$ Thus, the Court reaffirmed its support for tribal sovereign immunity in Michigan v. Bay Mills Indian Community, ${ }^{15}$ even though the

10 Not that these are the only two areas where limiting principles are at play. On "Limiting Principles" in Indian Free Exercise of religion cases, see Kristen A. Carpenter, Limiting Principles and Empowering Practices in American Indian Religious Freedoms, 45 Conn. L. Rev 387 (2012). In Lyng v. Northwest Indian Cemetery Association, 485 U.S. 439 (1988), for instance, the Court refused to enjoin the construction of a logging road through an area considered sacred to some Indians. The Court's refusal to give constitutional protections to such sites was heavily influenced by the lack of "limiting principles" in such claims. Thus, the Court stated "Respondents attempt to stress the limits of the religious servitude that they are now seeking to impose on the Chimney Rock area of the Six Rivers National Forest... Nothing in the principle for which they contend, however, would distinguish this case from another lawsuit in which they (or similarly situated religious objectors) might seek to exclude all human activity but their own from sacred areas of the public lands... No disrespect for these [religious] practices is implied when one notes that such beliefs could easily require de facto beneficial ownership of some rather spacious tracts of public property. Even without anticipating future cases, the diminution of the Government's property rights, and the concomitant subsidy of the Indian religion, would in this case be far from trivial." Id., at $452-453$.

${ }^{11}$ Three Affiliated Tribes v. Wold Engineering, 476 U.S. 877, 890 (1986).

${ }^{12}$ See Santa Clara Pueblo v. Martinez, 436 U.S. 49 (1978)

${ }^{13}$ Michigan v. Bay Mills Indian Community 134 S. Ct. 2024, 2031-32.

${ }^{14}$ For a recent overview of tribal and state sovereign immunity, see Richard B. Collins, To Sue and Be Sued: Capacity and Immunity of American Indian Nations, 51 Creighton L. Rev. 391, at 401-405.

15134 S. Ct. 2024 (2014). 
concept had only received lukewarm support sixteen years earlier in Kiowa Tribe $v$. Manufacturing Technologies. ${ }^{16}$ At issue in Bay Mills was whether the State of Michigan could sue the Tribe for opening a casino on lands that were allegedly not "Indian lands" under the Indian Gaming Regulatory Act (IGRA). ${ }^{17}$ IGRA made casino gaming on Indian land legal under certain conditions, one of which was for the tribe to have entered into a gaming compact with the State. ${ }^{18}$ IGRA also abrogated tribal sovereign immunity so that a state could sue a tribe alleged to be conducting gaming on Indian lands in violation of the tribal state compact. ${ }^{19}$ The problem facing Michigan was that it was alleging that the tribal gaming was illegal because it was not conducted on "Indian lands." Yet, IGRA only abrogated sovereign immunity to challenge illegal gaming conducted on "Indian lands." In other words, there was no abrogation of tribal sovereign immunity to challenge gaming NOT conducted on Indian lands. ${ }^{20}$ The Court in Bay Mills upheld the tribal immunity because

"As "domestic dependent nations," Indian tribes exercise sovereignty subject to the will of the Federal Government. Sovereignty implies immunity from lawsuits.

Subjection means (among much else) that Congress can abrogate that immunity as and to the extent it wishes. If Congress had authorized this suit, Bay Mills would have no valid grounds to object. But Congress has not done so: The abrogation of immunity in IGRA applies to gaming on, but not off, Indian lands. We will not rewrite Congress's handiwork." 21

In this area of the law, the limiting principle at first seems fair to Indian Nations in that it argues that they should be on a level playing field with states and therefore have the same degree of sovereign immunity that states enjoy. Thus, back in the mid 1980's, when Congress was debating the Indian Gaming Regulatory Act, the rallying battle cry of those in Congress opposed to what they perceived as a pro-tribal gaming bill sponsored by Morris Udall was that they wanted a "level playing field" when it came to

\footnotetext{
${ }^{16} 523$ U.S. 751 (1998), (stating "There are reasons to doubt the wisdom of perpetuating the doctrine... In our interdependent and mobile society, however, tribal immunity extends beyond what is needed to safeguard tribal self-governance. This is evident when tribes take part in the Nation's commerce. Tribal enterprises now include ski resorts, gambling, and sales of cigarettes to non-Indians. In this economic context, immunity can harm those who are unaware that they are dealing with a tribe, who do not know of tribal immunity, or who have no choice in the matter, as in the case of tort victims. These considerations might suggest a need to abrogate tribal immunity, at least as an overarching rule... we defer to the role Congress may wish to exercise in this important judgment." ) Id., at 758.

${ }^{17}$ Pub. L. 100-497, codified at 25 U.S.C. 2701-2721.

${ }^{18}$ The Tribal-State compact provisions are codified at 25 U.S.C. 2710.

${ }^{19}$ The abrogation of tribal sovereign immunity is contained in Section 7(d)(7)(A) (ii) of IGRA, codified at 25 U.S.C. 2701 et. seq.

${ }^{20} 25$ U.S.C 2703 of IGRA defines "Indian lands" as all lands within Indian reservations, lands held in trust by the United States for the benefit of Indians or Indian tribes, and lands held by Indians subject to a restriction against alienation and over which an Indian tribe exercises governmental power.

21134 S. Ct. 2024, 2039.
} 
gaming on Indian reservations. ${ }^{22}$ My immediate reaction at the time was to question why there should be a level playing field between tribes and anyone when the gaming was on Indian reservations. Eventually, I came to accept that the notion of a level playing field between states and tribes had some merit, ${ }^{23}$ but only if the tribes were awarded the same political dignity as States within our federalist system.

The Congress in IGRA ended up crafting a delicate balance between tribal and state interests requiring the tribes to enter into gaming compacts with states before gaming could be conducted on their reservations but also allowing tribes to sue states in federal court if the states failed to negotiate the compacts in good faith. ${ }^{24}$

The idea of a level playing field between tribes and states under IGRA was endorsed by Justice Sotomayor in her concurring opinion in Bay Mills when she stated

As the principal dissent observes, "comity is about one sovereign respecting the dignity of another." This Court would hardly foster respect for the dignity of Tribes by allowing States to sue Tribes for commercial activity on State lands, while prohibiting Tribes from suing States for commercial activity on Indian lands. Both States and Tribes are domestic governments who come to this Court with sovereignty that they have not entirely ceded to the Federal Government. ${ }^{25}$

The same level playing field idea in the area of gaming had been discussed in an earlier case, Chickasaw Nation v. United States, where Justice O'Connor in dissent objected to the majority's holding allowing the federal government to tax tribal gaming revenues pursuant to IGRA. Her dissent raised the argument that levelling the playing field with the states required the tribes to benefit from the same exemption from federal taxation.

If anything, congressional policy weighs in favor of the Nations. Congress' central purpose in enacting IGRA was "to provide a statutory basis for the operation of gaming by Indian tribes as a means of promoting tribal economic development, self-sufficiency, and strong tribal governments." Exempting Nations from federal gaming taxation in the same manner as States preserves the Nations' sovereignty and avoids giving state gaming a competitive advantage that would interfere with the Nations' ability to raise revenue in this manner. ${ }^{26}$

The Court, however, upset the delicate balance struck by Congress in IGRA in Seminole Tribe v. Florida when it ruled that Congress could not, under its Article I

\footnotetext{
${ }^{22}$ At the time, the author was Deputy Counsel for Indian Affairs for the Committee on Interior and Insular Affairs, chaired at the time by Congressman Morris Udall.

${ }^{23}$ But see Greg Ablavsky, Upper Skagit v. Lundgren: Deceptively Straightforward Case Raises Fundamental Questions about Native Nations, History, and Sovereignty, May $23^{\text {rd }}$ Stanford Blog, commenting on the case and questioning why tribe should be treated like states in this case when it is to their disadvantage when, in many other cases, they are not treated like states when it would be to their advantage.

${ }^{24}$ See Indian Gaming Regulatory Act at 15 U.S.C. 2710 (d)(7).

25134 S. Ct. 2024, 2042 (2014).

${ }^{26}$ Chickasaw Nation v. U.S., 534 U.S. 84, 99 (U.S., 2001).
} 
powers, abrogate the States' Eleventh Amendment sovereign immunity so as to allow Indian tribes to sue the states. ${ }^{27}$ Seminole Tribe highlights one of the potential problem with looking for a level playing field between tribes and states in the area of sovereign immunity: The States sovereign immunity is protected in the Constitution while tribal sovereign immunity is a doctrine of federal common law. This means that Congress can only abrogate state sovereign immunity pursuant to constitutional restrictions, ${ }^{28}$ while tribal sovereign immunity can be abrogated by Congress at will. The question here is whether a level playing field between tribes and states can still occur within these parameters. The odds for that are not that good, at least not as far as Indian gaming is concerned. ${ }^{29}$

\section{Level Playing Field with States in Off-Reservation sovereign immunity cases.}

In many contentious areas involving tribal versus non-tribal and state interests, the notion of congressional plenary power in Indian Affairs used to prevent the Court from venturing into unchartered territory and trying to come up with judicial solutions to conflicts that should be resolved by Congress. Tribal sovereign immunity is such an area. As stated by Justice Kagan in Bay Mills "We ruled that way for a single simple reason: because it is fundamentally Congress's job, not ours, to determine whether or how to limit tribal immunity. The special brand of sovereignty the tribes retain-both in nature and extent-rests in the hands of Congress." 30

Judicial respect for Congressional prerogatives, however, may be waning. ${ }^{31}$ One good example of this lack of patience with Congress and the Court's willingness to treat tribes the same as states for the purpose of reaching a level playing field is a somewhat surprising opinion by Justice Sotomoyor in Lewis v. Clark. ${ }^{32}$ The Court there refused to extend the tribe's immunity to a tribal employee alleged to have been negligent when operating a tribal vehicle within the scope of his employment but on a state highway located outside the Indian reservation. In coming to its decision, the Court did mention that "[T]he judgment will not operate against the Tribe. This is not a suit against Clarke in his official capacity. It is simply a suit against Clarke to recover for his personal actions, which will not require action by the sovereign or disturb the sovereign's property." ${ }^{33}$ However, the Court also took into account whether similar state employees would have enjoyed the State's sovereign immunity in such situations. After remarking that a state employee would not have enjoyed sovereign immunity in similar

\footnotetext{
${ }^{27} 517$ U.S. 44 (1996).

${ }^{28}$ See City of Boerne v. Flores, 521 U.S. 507 (1997)(requiring any such legislation necessary to enforce the $14^{\text {th }}$ Amendment to be congruent and proportional to the history of alleged constitutional violations.)

${ }^{29}$ But see, Ezekiel J.N. Fletcher, Negotiating Meaningful Concessions from States in Gaming Compacts to Further Tribal Economic Development Satisfying the Economic Benefit Test, 54 S.D. L. Rev. 419 (2009).

134 S. Ct. 2024, at 2037 (2014).

${ }^{31}$ See Skibine, The Supreme Court's Last 30 years of Federal Indian Law, supra note 5.

32137 S. Ct. 1285 (2017).

${ }^{33}$ Id., at 1291.
} 
circumstances, the Court stated "There is no reason to depart from these general rules in the context of tribal sovereign immunity."

A level playing field between tribes and other sovereigns concerning sovereign immunity was also considered in the Court's most recent sovereign immunity decision, Upper Skagit Indian Tribe v. Lundgren. ${ }^{35}$ In that case, the tribe had purchased a tract of land that used to be within the tribe's ancestral territory. When the tribe commissioned a survey of the land, it thought that a fence put in place by the adjoining landowners to demarcate their property was in the wrong place and notified them that it intended to remove the fence. The neighbors responded by filing a quiet title action in Washington state court, claiming title by adverse possession and mutual acquiescence. The Tribe answered by claiming sovereign immunity from such lawsuits in state court. After hearing oral arguments, the Supreme Court remanded. Although the Court held that the Washington Supreme Court had wrongly interpreted a previous decision as precluding the defense of tribal sovereign immunity, ${ }^{36}$ it remanded the case because the non-tribal party had raised an argument at the Supreme Court that had not be raised in the lower courts or even in the initial cert briefs. ${ }^{37}$ That argument relied on the "immovable property" doctrine, a common law doctrine under which "sovereigns enjoyed no immunity from actions involving immovable property located in the territory of another sovereign." 38

Four Justices joined Justice Gorsuch's opinion. To these Justices, the case should be remanded because "Determining the limits on the sovereign immunity held by Indian tribes is a grave question; the answer will affect all tribes, not just the one before us; and the alternative argument for affirmance did not emerge until late in this case." ${ }^{39}$ Only Justices Thomas and Alito in dissent were willing to decide the issue immediately and for them the tribe's immunity in this area should be treated just like the immunity of other sovereigns. According to Justices Thomas and Alito, "the immovable property exception has been hornbook law almost as long as there have been hornbooks." Therefore, the defense of sovereign immunity should not be available to the tribe in this case.

Justice Gorsuch was right, however, that determining whether the tribes' sovereign immunity should be larger than that of other sovereigns is a "grave question," and one that "may turn out to be more complicated than the dissent promises." Whether the immovable property exception rules the day as far as states are concerned

\footnotetext{
${ }^{34}$ Id., at $1290-91$.

35138 S. Ct. 1649 (2018).

${ }^{36}$ Id., at 1653, interpreting County of Yakima v. Confederated Tribes of the Yakima Nation, 502 U.S. 251 (1992).

37 Id., at 1654 .

${ }^{38}$ Id., at 1653

${ }^{39}$ Id. at 1654

40 Id., at 1657 (Thomas dissenting).

${ }^{41}$ Id., at 1654 (Roberts concurring).
} 
is very debatable. Justice Roberts in his concurrence asserted that "The same rule applies as a limitation on the sovereign immunity of States claiming an interest in land located within other States, ${ }^{42}$ but many states filed amicus briefs with the Court arguing that the doctrine is antiquated and should no longer be applicable. ${ }^{43}$

After acknowledging that the only question in this case was "whether different principles afford Indian tribes a broader immunity [than other sovereigns] from actions involving off-reservation lands," 44 Justice Roberts added "But if it turns out that the rule does not extend to tribal assertions of rights in non-trust, non-reservation property, the applicability of sovereign immunity in such circumstances would, in my view, need to be addressed in a future case." ${ }^{45}$ I have a feeling that if the lower court on remand finds the immovable property doctrine not applicable to tribes as it is to states, the level playing field principle will weigh heavily in influencing the likes of Justices Roberts and Kavanaugh to join Justices Thomas and Alito should this case makes its way back to the Supreme Court. These four would only need one more to constitute a majority. If I was the tribal attorney, I would be extremely apprehensive in bringing this case or a similar one back to the Court.

A case about tribal sovereign immunity involving off-reservation conduct may already be on the horizon. In Wilkes v. PCl Gaming authority, ${ }^{46}$ the Alabama Supreme Court held that the Poarch Band of Creek Indians could not invoke sovereign immunity to protect the Tribe from a lawsuit filed by non-Indians over an automobile accident that occurred outside the reservation. The facts are not good for the Tribe. The non-tribal parties were alleging that a tribal employee driving a tribal vehicle was under the influence of alcohol when her vehicle collided with the plaintiffs' automobile. Because the plaintiffs alleged that tribal officials were aware of the driver's drinking problem, they are suing the tribe for negligence and wantonness premised on the Tribe's hiring, retaining, and supervising the driver of the vehicle.

The Alabama Court was aware that many lower federal courts, as well as other state courts, have upheld tribal sovereign immunity in similar cases. However, it relied heavily on Justice Kennedy's dicta in Kiowa Tribe v. Manufacturing technologies to the effect that there were "reasons to doubt the wisdom of perpetuating the doctrine." ${ }^{\text {"It }}$ It also relied on footnote 8 of Justice Kagan's more recent Bay Mills opinion to the effect that the Court had never "specifically addressed (nor as far as we are aware, has Congress) whether immunity should apply in the ordinary way if a tort victim, or other plaintiff who has not chosen to deal with a tribe, has no alternative way to obtain relief

\footnotetext{
42138 S. Ct. at 1655, citing Georgia v. Chattanooga, 264 U.S. 472, 480-482 (1924).

${ }^{43}$ See Jenn Weddle Guest Post on the May $23^{\text {rd }} 2018$ Turtle Blog.

${ }^{44} 138 \mathrm{~S}$. Ct, at 1655 (Roberts concurring).

${ }^{45}$ Id., at 1656.

${ }^{46} 2017$ WL 4385738.

${ }^{47} 523$ U.S. 751,756 (1998). The full text of Justice Kennedy's comment is replicated at note 15, supra.
} 
for off-reservation commercial conduct." ${ }^{48}$ The Tribe has petitioned the United States Supreme Court for certiorari. Strangely, the tribal petition never mentioned whether the plaintiffs could sue the tribe in tribal court. Instead, the Tribe addressed Baymills' footnote 8 by pointing out that pursuant to Lewis v. Clark, the plaintiffs had already filed a lawsuit against the driver of the tribal truck. ${ }^{49}$ Whether this option will be enough to satisfy a majority of the Court should the Court decides to take the case is highly debatable.

\section{Problems with treating tribes like states when it comes to Sovereign Immunity: The Allergan litigation.}

A case perhaps making its way to the Supreme Court is the Allergan Restasis litigation. The litigation involved two different fronts. First, Allergan sued in federal court seeking to protect its Restasis patents. Secondly, Mylan Pharmaceuticals petitioned the Patent Trial and Appeals Board (PTAB), for inter partes review (IPR) of the Restasis patents. Inter Partes Review is an administrative procedure set up in the America Invents Act to allow the Patents and Trademark Office (PTO) to review expeditiously the validity of a patent that was previously awarded. ${ }^{50}$ After the litigation had started, Allergan and the St. Regis Mohawk Tribe notified the federal court and the PTAB that all of Allergan's challenged patents had been assigned to the St. Regis Mohawk Tribe and that the tribe had granted back to Allergan the exclusive license to the patents. Under the deal, the tribe received $\$ 13.5$ million upon execution of the agreement and will receive $\$ 15$ million in annual royalties after that.

In the federal court proceedings, after ordering the joinder of the tribe as a coplaintiff, the judge was concerned by the lack of a limiting principle if tribal sovereign immunity was upheld. Thus, he stated that if Allergan's tactic was successful, others could also use it and this "could spell the end of the PTO's IPR program which was a central component of the American Invents Act of 2011." Although the court eventually held that the Restasis patents were invalid based on obviousness, this ruling was appealed to the Federal Circuit. Similarly, in the inter partes Review, the PTAB refused to dismiss the proceedings in spite of tribal sovereign immunity. ${ }^{52}$ The PTAB spent most of its decision arguing that because Allergan was the true owner of the patents and can defend the interest of the tribe adequately, the IPR proceedings could continue without the tribe ${ }^{53}$ However, after observing that the Tribe had not pointed to

\footnotetext{
${ }^{48}$ Michigan v. Bat Mills Indian Community, 134 S. Ct 2024, 2036, n. 8.

${ }^{49}$ Brief for the Petitioners in Poarch Band of Creeks v. Wilkes, at page 25. For discussion of Lewis v. Clark, see discussion at notes supra at notes 31-33.

${ }^{50}$ Pub. L. 112-29, 125 Stat. 284.

${ }^{51}$ Allergan v. Teva Pharmaceuticals, 2017 WL 4803941. The judge also intimated that if it was up to him, the agreement between the Tribe and Allergan would be set aside as against Public Policy.Id., at 2017 WL 4803941.

${ }_{52}$ Mylan Pharm., Inc. v. St Regis Mohawk Tribe, No. IPR2017-01127 (PTAB, Feb 23, 2018)

${ }^{53}$ Mylan Pharm. V. St Regis Mohawk Tribe, pp. 18-19. The Board also ruled that even if the Tribe had sovereign immunity, it was not an indispensable party under Rule 19B of the Rules of Federal Civil Procedures. These parts of the Board's decision are not the concern of this Article as they involve
} 
any authority confirming that the same principles supporting state sovereign immunity should be applicable to tribal immunity ${ }^{54}$ the Board held that tribal sovereign immunity, generally speaking, does not apply to IPR type proceedings. ${ }^{55}$ To make this argument, the Board argued that IPR proceedings are akin to federal enforcement proceedings brought by a federal agency. Just like the federal court's ruling, the PTAB's decision was also appealed to the Federal Circuit. ${ }^{56}$

On Appeal from the Board's decision, the Tribe insisted that tribal sovereign immunity is applicable to IPR proceedings based on the following arguments. ${ }^{57}$ First, the Board has previously recognized sovereign immunity when invoked by state universities, ${ }^{58}$ and there are no meaningful differences between the Universities and the tribe's invocation of sovereign immunity in this context. Secondly, sovereign immunity is applicable in federal administrative agency proceedings, ${ }^{59}$ and inter partes review is such a proceeding. Third, inter partes Review cannot be categorized as a federal agency enforcement proceeding where sovereign immunity would not be available. ${ }^{60}$

The Court of Appeals for the Federal Circuit did not agree with the Tribe's arguments. ${ }^{61}$ Instead, relying partly on a recent Supreme Court case ${ }^{62}$ for the proposition that IPR is a matter "which arise[s] between the Government and persons subject to its authority in connection with the performance of the constitutional functions of the executive or legislative departments,"63 it agreed with the Appellees that sovereign immunity was not applicable to the IPR process. The Court began by stating "IPR is neither clearly a judicial proceeding instituted by a private party nor clearly an enforcement action brought by the federal government. It is a "hybrid proceeding" with "adjudicatory characteristics" similar to court proceedings, but in other respects it "is less like a judicial proceeding and more like a specialized agency proceeding." 64 Therefore, the Court concluded that "IPR is more like an agency enforcement action

primarily areas of civil procedure and patent law that do not implicate tribal interests under federal Indian law.

${ }^{54}$ Id., at pp 8-10

${ }^{5} \mathrm{Id}$., at $11-17$.

${ }^{56}$ See Petitioner's brief, 2018 WL 1989302.

${ }^{57}$ See Petitioner's brief, 2018 WL 1989302.

${ }^{58}$ See Covidien v. University of Florida, IPR2016-01274 (Jan. 25, 2017) NeoChord Inc., v. University of Maryland. No. IPR2016-00208 (May 23, 2017), Reactive Surfaces v. Toyota Motor, IPR2016-01914 (July 13, 2017).

${ }^{59}$ See Federal Maritime Commission v. South Carolina State Ports Authority, 535 U.S. 743 (2002).

${ }^{60}$ The Tribe also continued to argue that the Board was wrong in holding that Allergan was the effective patent owner and, therefore, could not be withdrawn as a party to the proceedings. Similarly, the Tribe argued that the Board was wrong to find that even if Allergan was the effective patent owner, the Tribe was not an indispensable party under the Rule $19 \mathrm{~B}$ of the federal Rules of Civil Procedure

${ }^{61}$ See Saint Regis Mohawk Tribe v. Mylan Pharmaceuticals, 896 F.3d 1322 (2018)

${ }^{62}$ Oil States Energy Services v. Greene's Energy Group, 138 S. Ct. 1365 (2018) (Upholding the constitutionality of Inter Partes Review because the revocation of a previously granted patent involved adjudication of a public right and, therefore, could be delegated to a non-Article III Court.

${ }^{63}$ Saint Regis Mohawk Tribe v. Mylan Pharmaceuticals Inc., 896 F.3d 1322,1327( 2018).

${ }^{64}$ Id., at 1326. 
than a civil suit brought by a private party." ${ }^{65}$ As such, tribal immunity was not implicated. ${ }^{66}$ Whether the Court is correct in its conclusion that IPR is more like an agency enforcement action is beyond the scope of this Article.$^{67}$ In some ways, the ground used by the court may be one of the least harmful to tribal interests generally speaking, as the rational used should not impact tribal sovereign immunity beyond the narrow confines of IPR proceedings.

This Article does not take a position on the wisdom of the tribal-Allergan agreement from a social policy perspective. ${ }^{68}$ Neither does it take a position on whether sovereign immunity should generally be available to either states or tribes in such cases. ${ }^{69}$ However, because this Article argues that there should be a level playing field between tribes and states, the concern here is that although the tribe lost on the sovereign immunity issue, eventually, the states may not. Therefore, this article will next focus on whether there are meaningful differences between invocation of state and tribal sovereign immunity in the patent IPR context.

An argument made by the Appellees in their brief was that tribal sovereign immunity should not apply to the St. Regis Mohawk Tribe in this case because the agreement with Allergan was a "sham" devised to avoid the patents being challenged in agency or court proceedings. ${ }^{70}$ Although the PTAB and the Federal Circuit did not address this argument, the federal district court judge in the parallel Federal court proceeding stated

The Court has serious concerns about the legitimacy of the tactic that Allergan and the Tribe have employed. The essence of the matter is this: Allergan purports to have sold the patents to the Tribe, but in reality it has paid the Tribe to allow Allergan

\footnotetext{
${ }^{65}$ Id., at 1327.

${ }^{66}$ As stated by the Court, "The Director's important role as a gatekeeper and the Board's authority to proceed in the absence of the parties convinces us that the USPTO is acting as the United States in its role as a superior sovereign to reconsider a prior administrative grant and protect the public interest in keeping patent monopolies within their legitimate scope." Id., 1329.

${ }^{67}$ The Court essentially gave four reasons for its conclusion. First, the Agency makes the ultimate decision whether to institute the review proceedings. Second, The Board may choose to continue the review even if the petitioner chooses not to participate. Third, the procedures used by the PTAB do not mirror the Federal Rules of Civil Procedure. Fourth, "IPR is not necessarily a proceeding in which Congress contemplated tribal immunity to apply." That last ground is somewhat perplexing as the general rule is that Congress has to explicitly abrogate tribal immunity for it not to apply.

${ }^{68}$ For arguments that this agreement may not have been such a good idea, see Cecilia (Yixi) Cheng \& Theodore T. Lee, When Patents are Sovereigns: The Competitive Harms of Leasing tribal Immunity, 127 Yale L.J. F. 848 (2018).

${ }^{69}$ Although there are some good arguments against applying tribal or state sovereign immunity in this area. See for instance the concurring opinion of Judge Bisk in Ericsson v, U. of Minnesota, IPR201701186 (Dec. 19, 2017), 2017 WL 6517563 at p. 5-7.

${ }^{70}$ See Appellee's brief at at p. 27.
} 
to purchase-or perhaps more precisely, to rent-the Tribe's sovereign immunity in order to defeat the pending IPR proceedings in the PTO. ${ }^{71}$

In order to buy into this line of reasoning, a court would first have to distinguish cases where state universities have successfully invoked their sovereign immunity in IPR proceedings. It is true that State Universities are usually involved in the development of patents while Indian tribes are not. In their appeals brief, for instance, the Appellees took the Tribe to task for suggesting that it has done "nothing more than follow the model created by state universities," stating:

That is not so. State universities' patent portfolios are often derived from research funded by the State, while the Tribe funded none of the research and development involving these patents... The Tribe was a complete stranger to Restasis (and to pharmaceutical patents in general) until Allergan paid it to enter into a transaction after the close of evidence in these IPRs. ${ }^{72}$

Although some of the cases like Covidian and Eriksson did not involve any "transfer" of patents to universities, ${ }^{73}$ other like Reactive Surface and NeoChord did. ${ }^{74}$ However, the university cases have so far not involved patents being transferred to a State University so that it could license them back in order for the licensee to benefit from the licensor's sovereign immunity. On the other hand, it is true that in non-IPR contexts, the states have previously manipulate their sovereign immunity in order to avoid liability. For instance, in their appellate brief to the Circuit, the Tribe cited 4 cases for the proposition that other Sovereigns also use immunity to avoid liability in pending lawsuits. ${ }^{75}$ While the first two cited cases, Oracle Am and Kroll, can be distinguished on their facts, the last two cannot as they involve transfer of liability from a non-sovereign to a state entity that resulted in successful assertion of state sovereign immunity. In Cabrero, especially, the transfer was done for the very purpose of avoiding liability. ${ }^{76}$

Allowing sovereign immunity to be invoked in some cases but not in others would mean having a court dictate to a sovereign when use of sovereign immunity is proper. That is problematic. The tribes, like other sovereigns, are involved in myriads of economic activities. The court would have to devise a test to distinguish among those. This is exactly what the Court refused to do in Kiowa tribe v. Manufacturing

\footnotetext{
${ }^{71}$ Allergan, Inc. v. Teva Pharmaceuticals USA, Inc., 2017 WL 4619790, at 2 (E.D.Tex., 2017). The Court also stated, however, that the tribal sovereign immunity issue was not before the Court but should be decided in the PTAB proceedings.

722018 WL 2234327 at p. 25.

${ }^{73}$ Covidien LP v. U of Florida research Foundation, No. IPR2016-01274 (January 25, 2017), Ericsson v, U. of Minnesota, IPR2017-01186 (Dec. 19, 2017).

${ }^{74}$ NeoChord Inc., v. University of Maryland. No. IPR2016-00208 (May 23, 2017), Reactive Surfaces v. Toyota Motors, IPR2017-00572 (July 13, 2017).

${ }^{75}$ Oracle Am., Inc. v. Oregon Health Ins. Exch. Corp., 145 F. Supp. 3d 1018, 1042-43 (D. Or. 2015)), Kroll v. Bd. of Trustees. of Univ. of III., 934 F.2d 904, 910 (7th Cir. 1991, Surprenant v. Mass. Tpk. Auth., 768 F. Supp. 2d 312, 318 (D. Mass. 2011), and Maysonet-Robles v. Cabrero, 323 F.3d 43, 51 (1st Cir. 2003). ${ }^{76} 323$ F.3d 43, 51 (1st Cir. 2003)(case dismissed on sovereign immunity grounds when assets of nonsovereign entity were transferred during the litigation to a sovereign entity created solely for purpose of asserting sovereign immunity.)
} 
Technologies when it did not restrict the use of tribal sovereign immunity for cases involving tribal commercial activities and arising outside Indian reservations. ${ }^{77}$

A more serious argument made by the Appellees in their brief to the Federal Circuit was that even if state universities can invoke sovereign immunity in such cases, the tribes cannot because, unlike State sovereign immunity which is mandated under the Eleventh Amendment to protect norms of federalism, tribal sovereign immunity is only a doctrine of federal common law. ${ }^{78}$ The Federal Circuit refused to enter this debate, concluding its opinion by stating "In this case we are only deciding whether tribal immunity applies in IPR. While we recognize there are many parallels, we leave for another day the question of whether there is any reason to treat state sovereign immunity differently," ${ }^{79}$ The reluctance of the Federal Circuit to make a pronouncement on the application of state sovereign immunity is puzzling because recent decisions of the PTAB have already held that state sovereign immunity is applicable to inter partes review, ${ }^{80}$ and so did the Federal Circuit in Vas-Cath Inc., v. Curators of the University of Missouri. $^{81}$

Congress may in fact lack the constitutional authority to abrogate state sovereign immunity for the purpose of inter partes review. The Court in Seminole Tribe v. Florida held that Congress could not abrogate state sovereign immunity under its Article I powers. ${ }^{82}$ Therefore, neither the Patent Clause, ${ }^{83}$ nor the Commerce Clause ${ }^{84}$ are legitimate sources of power for Congress in this area. This leaves Section 5 of the $14^{\text {th }}$ Amendment, ${ }^{85}$ as the only potential source of authority. However, in Florida Prepaid $v$. College Savings Bank, ${ }^{86}$ the Supreme Court held that even if the Patent Remedy Act was enacted under the Enforcement Clause of the $14^{\text {th }}$ Amendment, it still could not meet the City of Boerne congruent and proportional test and was therefore not "appropriate" legislation under Section $5 .{ }^{87}$ The PTAB in Neochord v. University of

\footnotetext{
${ }^{77} 523$ U.S. 751 (1998). That holding was reaffirmed more recently in Michigan v. Bay Mills Indian Community, 124 U.S. 2024 (2014).

${ }^{78} 2018$ WL 2234327, at p. 17.

${ }^{79} 896$ F.3d 1322, 1329 (2018).

${ }^{80}$ See Covidien LP v. U of Florida research Foundation, No. IPR2016-01274 (January 25, 2017), NeoChord Inc., v. University of Maryland. No. IPR2016-00208 (May 23, 2017), Reactive Surfaces v. Toyota Motors, IPR2017-00572 (July 13, 2017), and Ericsson v, U. of Minnesota, IPR2017-01186 (Dec. 19, 2017).

${ }^{81} 473$ F.3d 1376 (Fed. Cir. 2007).

${ }^{82} 517$ U.S. 44 (1996).

${ }^{83}$ Section 8 clause 8 of Article I gives Congress the power to "promote the Progress of Science and useful Arts, by securing for limited Times to Authors and Inventors exclusive Rights to their respective writings and Discoveries."

${ }^{84}$ Article I, Section 8, Clause 3.

${ }^{85}$ Section 5 of the $14^{\text {th }}$ Amendment states "The Congress shall have power to enforce this Article by appropriate legislation."

${ }^{86} 527$ U.S. 627 (1999).

${ }^{87}$ See 521 U.S. 507 (1997) (stating that before Congress can abrogate a state's sovereign immunity pursuant to its power under section 5 of the $14^{\text {th }}$ Amendment, "There must be a congruence and
} 
Maryland followed suit and held that Congress could not have abrogated the states' sovereign immunity under Section 5 of the $14^{\text {th }}$ Amendment when it established the IPR procedures. ${ }^{88}$ The Allergan litigation, therefore, may be another example where treating tribes like states in the hope of reaching a level playing field may just not be possible because of constitutional constraints.

\section{PART III: Limiting Principles in Off Reservation Indian Treaty cases:}

The Foundational principles of treaty interpretation are that treaties made with Indian nations are to be construed the way the Indians understood them at the time of the signing. ${ }^{89}$ Furthermore, ambiguous expressions are supposed to be interpreted to the Indians' benefit. ${ }^{90}$ Finally, although only Congress can abrogate Indian treaties, a treaty will only be considered abrogated if a court finds clear evidence that Congress actually considered the Indians' treaty rights and decided to abrogate them. ${ }^{91}$

Limiting principles tending to achieve a level playing field between tribes and states have been at play in regulations of hunting and fishing treaty rights. Thus, states have been allowed to regulate Tribal fishing rights both off and even on Indian reservations as long as the regulations are necessary for the conservation of a scarce renewable natural resource and as long as they do not discriminate against tribal members. ${ }^{92} \mathrm{~A}$ good example of a limiting principle in this area was the use of the term "moderate living" used by Justice Stevens in the 1979 Washington treaty fishing case. ${ }^{93}$ After agreeing that the 1855 treaty of Point Elliott reserved to the Tribes up to $50 \%$ of the harvestable fish resource, Justice Stevens added:

It bears repeating, however, that the $50 \%$ figure imposes a maximum but not a minimum allocation... [t] a natural resource that once was thoroughly and exclusively exploited by the Indians secures so much as, but no more than, is necessary to provide the Indians with a livelihood - that is to say, a moderate living. ${ }^{94}$

No one seems to really know where Justice Stevens derived this "moderate living" standard, although some speculate that he just came up with it in order to persuade other Justices to join his opinion. As stated by the late Dean David Getches "In the third draft of his opinion, [Justice Stevens] added language to stress that the right of tribes stopped when they reached a "moderate" living standard, an idea not offered by any

proportionality between the injury to be prevented or remedied and the means adopted to that end.") Id., at 520.

${ }^{88}$ IPR2016-00208, at p. 12.

${ }^{89}$ See Minnesota v. Mille Lacs Band of Chippewa Indians, 526 U.S. 172, 196 (1999).

${ }^{90}$ See Choctaw nation v. Oklahoma397 U.S. 620, 631 (1970).

${ }^{91}$ United States v. Dion, 476 U.S. 734 (1986).

${ }^{92}$ See Puyallup Tribe v. Department of Game, 433 U.S. 165, 174-177 (1977).

${ }^{93}$ Washington v. Washington State Commercial Passenger Fishing Vessel Ass'n, 443 U.S. 658, (1979).

${ }^{94}$ Id., at 686-87. 
party or suggested in any of the briefs... Chief Justice Burger characterized Stevens' approach as "an 'arbitration' holding," and thus Stevens secured a majority vote."

The "moderate living" standard became a source of controversy during the Supreme Court's oral argument in the recently heard "culverts" case. ${ }^{96}$ At issue in the case was whether the State of Washington had a duty to modify many of its culverts so that they could allow the salmon to pass through. ${ }^{97}$ The Ninth Circuit held that in building and maintaining barrier culverts, Washington had violated its obligations under the treaties. ${ }^{98}$ At the oral argument, it seems that a majority of the Justices were attempting to find a limiting principle defining the scope of the State's duty to prevent its activities from reducing the salmon runs. The State argued that the $9^{\text {th }}$ Circuit's opinion had no limiting principle on the treaty right of the tribes and if left intact, the opinion would allow tribes to regulate all activities within the state that may have an impact on the salmon population. ${ }^{99}$

One area of disagreement between the tribes and the State was whether the $9^{\text {th }}$ Circuit had used the "moderate living" standard in order to hold that the State of Washington had a duty to repair hundreds of culverts preventing or impairing the salmon from passing through. The problem was that the $9^{\text {th }}$ Circuit panel decision was far from pellucid on this point. On one hand, it first stated "even in the absence of an explicit promise [by Governor Stevens], we would infer a promise that the number of fish would always be sufficient to provide a "moderate living" to the Tribes." 100 However, it followed that by stating "The "measure of the State's obligation" therefore depends "on all the facts presented" in the "particular dispute" now before us." 101 While this statement seems to call for an ad-hoc fact intensive inquiry without a precise standard, the 9th Circuit concluded

The facts presented in the district court establish that Washington has acted affirmatively to build and maintain barrier culverts under its roads... If these culverts were replaced or modified to allow free passage of fish, several hundred thousand additional mature salmon would be produced every year. Many of these mature salmon would be available to the Tribes for harvest. Salmon now available for harvest are not sufficient to provide a "moderate living" to the Tribes. ${ }^{102}$

\footnotetext{
${ }^{95}$ David Getches, Conquering the Cultural Frontier: The New Subjectivism of the Supreme Court in Indian Law, 84 Cal. L. Rev. 1573, 1638-39 (1996).

${ }^{96}$ See Washington v. United States, Oral arguments held on April 18, 2018, 138 S. Ct. 1832 (2018)).

${ }^{97}$ The Court also agreed with previous findings that there had been a substantial degradation of the Salmon habitat causing a significant reduction in the number of salmons and that the barrier culverts were a primary cause of the fish habitat degradation. $853 \mathrm{~F} .3 \mathrm{~d}$ at 961.

98 United States v. Washington, 853 F.3d 946, 966 ( $9^{\text {th }}$ Cir. 2017)

${ }^{99}$ Transcript of oral argument, p. 4.

${ }^{100}$ Id., at 965.

${ }^{101}$ Id., at 966 .

102 Id.
} 
So what exactly was the role of the "moderate living" standard? When the $9^{\text {th }}$ Circuit denied the petition for re-hearing en banc, Judges Fletcher and Gould who were members of the panel decision, strongly objected to the dissent characterizing their holding as guaranteeing the tribal fishermen a moderate living standard, stating

Our opinion does not hold that the Tribes are entitled to enough salmon to provide a moderate living, irrespective of the circumstances... Nor do we hold that the promise is valid against all human-caused diminutions, or even against all State-caused diminutions. We hold only that the State violated the Treaties when it acted affirmatively to build roads across salmon bearing streams, with culverts that allowed passage of water but not passage of salmon. ${ }^{103}$

During the oral argument at the Supreme Court, the United States and the tribes denied advocating that the state had a duty to make sure that Indian fishermen could achieve a "moderate living standard" through fishing activities. ${ }^{104}$ But if that is not the standard for the state's duty, what is?

An analysis of the $9^{\text {th }}$ Circuit decision reveals that it relied on two main arguments: First, the treaty had to be construed the way the Indians understood it. As stated by the $9^{\text {th }}$ Circuit,

The Indians did not understand the Treaties to promise that they would have access to their usual and accustomed fishing places, but with a qualification that would allow the government to diminish or destroy the fish runs. Governor Stevens did not make, and the Indians did not understand him to make, such a cynical and disingenuous promise. The Indians reasonably understood Governor Stevens to promise not only that they would have access to their usual and accustomed fishing places, but also that there would be fish sufficient to sustain them. They reasonably understood that they would have, in Stevens' words, "food and drink ... forever." 105

Secondly, the treaty had to be interpreted in a manner consistent with fulfilling the "purpose" of the treaty. ${ }^{106}$ The purpose of the treaty was to guarantee the Indians an adequate or sufficient supply of fish to feed themselves.

The problem for the State was that in the lower courts, it had argued that it had no duty whatsoever to protect the tribes' treaty rights from potentially nefarious state initiated activities. ${ }^{107}$ At the Supreme Court, however, it seemed to change course and when asked if there was any limits on state activities tending to reduce the salmon population, the State's Attorney General first mentioned that the state could not erect a barrier "causing a large decline in a particular river that is not justified by substantial

\footnotetext{
${ }^{103}$ United States v. Washington, 864 F.3d 1017, 1020 (C.A.9, 2017).

${ }^{104}$ Transcript of oral argument, at pp. 35, 57 and 60.

${ }^{105}$ United States v. Washington, 853 F.3d 946, 964.

${ }^{106} 853$ F.3d 946, at 965.

${ }^{107} 853$ F.3d at 962.
} 
compelling interests." ${ }^{108}$ When pushed further about what is meant by a "large" decline, the state's Attorney General mentioned that the state could not do something that would cause a substantial degradation of the salmon habitat resulting in a reduction of the number of salmons by $50 \%$ or more. ${ }^{109}$

According to the State, because all parties modified the arguments in their briefs to the Supreme Court, the Case should be remanded once the Court decided which standard would control the State's duty. The Supreme Court affirmance of the $9^{\text {th }}$ Circuit decision by an equal 4-4 vote shows that the Justices may have been hopelessly deadlocked as to what that standard or limiting principle should be. ${ }^{110}$

Limiting principles could also come into play in Cougar Den v. Washington, a case the Court will hear next term. ${ }^{111}$ At stake in the case is whether the state of Washington could impose on a tribal corporation a tax for fuel used for the propulsion of motor vehicles on state highways. The Tribe is arguing that Article III of an 1855 treaty, securing to tribal members "the right, in common with citizens of the United states, to travel upon all public highways," 112 preempted the state fuel tax because the fuel is necessary for trvel upon the public highway. The State argued that this case is not about the right to travel but primarily about the right to trade which is not one of those rights guaranteed under the treaty. The tribe disagrees, arguing that the right to trade is, in some cases such as this one, subsumed in the right to travel. The State Supreme Court agreed with the Tribe. ${ }^{113}$ After stating that the treaty has to be interpreted the way the Indians understood it at the time of the signing, the State Court remarked that at the time the treaty was signed, the right to travel for the purpose of bringing goods to and from the reservation was essential to the Indians.

There is room for disagreement about whether the facts of the case involve the right to trade and not the right to travel or vice versa. However, the Court's decision to grant cert may signify that at least four Justices do not see enough of a limiting principle in the state Supreme Court's interpretation of the treaty. These Justices may more readily agree with the dissent when it stated

[w] hat this ruling puts at risk is Washington's, and potentially other states', ability to tax goods consumed within its borders. A simple extension of the majority's logic would allow nontribal members to avoid the imposition of state use, excise, or sales tax on goods they consume through a contrived transport by Yakama Nation or Nez

\footnotetext{
${ }^{108}$ Transcript of oral arguments at p. 5, 12 and 25. The United States answered that under established Supreme Court precedent, the state could only regulate the salmon runs for the purpose of conservation. Id., at p. 46, relying on a trio of Puyallup decisions, the most notable being Puyallup Tribe v. Department of Game, 433 U.S. 165, 174-177 (1977)

${ }^{109}$ Id., at pp 14, and 16.

${ }^{110}$ Washington v. United States, 138 S. Ct. 1832 (2018) (Affirming by an equally divided Court).

${ }^{111}$ Docket No. 16-1498, petition for Certiorari granted June $25^{\text {th }}, 2018$.

${ }^{112}$ Treaty with the Yakamas, 12 Stat. 951, at 952-953 (1855).

${ }^{113}$ Cougar Den, Inc. v. Washington State Department of Licensing, 392 P.3d 1014 (2017).
} 
Perce tribal members. The majority provides no clear limits. Transport is necessary to bring many goods to market. ${ }^{114}$

In its brief to the Supreme Court, the State picked up on the dissent's argument and argued that if the Supreme Court were to adopt the State Court's position that any trade that requires the use of public roads involves the right to travel, "the consequences for state and federal taxing powers would be immense."115 Therefore, the State urged the Court to adopt the principle that any exemptions from state taxes imposed on off reservation activities should be expressly authorized under federal law. ${ }^{116}$ If the Washington Court's decision did not contain enough of a limiting principle, the State's argument here imposes too much of one. The Tribe on the other hand comes up with a different limiting principle. In its brief to the Supreme Court, it argued that "the right-totravel provision would not preempt taxation of acts distinct from the exercise of treaty rights, such as off-reservation economic transactions occurring before or after the highway travel." ${ }^{\text {117 }}$ Whether this is enough of a limiting principle for the Court remains to be seen. Perhaps a good compromise would be to hold that the state cannot impose its fuel tax on any tribal travel involving bringing goods to and from the reservation.

Herrera $v$. Wyoming is another case involving off reservation treaty rights that the Court will hear next term. ${ }^{118}$ In the case, Mr. Herrera, a member of the Crow Tribe, received a citation from Wyoming for hunting in the Big Horn National Forest where he had killed three elks during the off-season while outside the reservation. Herrera pleaded not guilty, contending that he was exercising his hunting rights pursuant to Article IV of $t$ the 1868 Treaty between the United States and the Crow tribe. ${ }^{119}$ In that treaty, the Crow tribe ceded vast amounts of land to the United States but in Article IV, it insisted that tribal members shall continue to "have the right to hunt on the unoccupied lands of the United States." 120

In its petition against the grant of Certiorari, the State first argued that the Plaintiffs' case was barred by the doctrine of collateral estoppel as the identical issue had already been decided by the Tenth Circuit in 1995 in Crow Indian Tribe v. Repsis. ${ }^{121}$ In Repsis, the $10^{\text {th }}$ Circuit held that under a United States Supreme Court precedent, Ward $v$. Racehorse ${ }^{122}$ the Crow Tribe's treaty rights were abrogated upon Montana's admission

\footnotetext{
${ }^{114}$ Id., at 1024-25. The Court also added "Does this mean all goods transported to market by Yakama Nation members, regardless of the identity of the buyer and the purpose of transport, are exempt from state tax? Nothing indicates any of the parties understood the Treaty of 1855 to provide for such a right. Yet the majority's ruling seems to create just such a right." Id., at 1025.

${ }^{115}$ Brief for the Petitioner, at p. 39, 2018 WL 3854756.

${ }^{116}$ Id., at pp. 18-20.

${ }^{117}$ Washington State Department of Licensing v. Cougar Den, Inc., 2018 WL 4504294 (U.S.), 36

(U.S.,2018).

${ }_{18}$ Petition for Cert granted, June 29, 2018, 2018 WL 3148285.

${ }^{119}$ Treaty with the Crow Tribe of Indians, 15 Stat. 649 (1868).

${ }^{120}$ Id., 15 Stat. 650.

${ }^{121} 73$ F.3d $982\left(10^{\text {th }}\right.$ Cir. 1995).

122163 U.S. 504 (1896).
} 
into the Union "on an equal footing" with the original thirteen colonies. The tribal plaintiff in his petition argued that a subsequent decision by the Supreme Court, Minnesota $v$. Mille Lacs Band of Chippewa Indians, ${ }^{123}$ had overturned Ward $v$. Racehorse. Therefore, Res Judicata should not bar the litigation. The state countered that Mille Lacs did not completely overturn the Racehorse decision. Therefore, the issue was precluded. ${ }^{124}$

Should the tribe convince the Court that the Mille Lacs decision completely overturned Racehorse and, therefore, the treaty right survived Montana's admission into the Union, the Court may have to decide the core treaty interpretation issue: Did the creation of a National Forest terminate the status of the land on which Herrera was hunting as "unoccupied lands of the United States." ${ }^{125}$ Herrera and the United States take the position that the term "unoccupied lands of the United States" refer to lands that have not been settled by non-Indians under the Homestead laws. On the other hand, the State is arguing that lands comprising a National Forest can no longer be settled and therefore these lands are no longer unoccupied.

The United States is also arguing that hunting is not incompatible with the creation of a National Forest. Except for Repsis, most of the lower courts that have considered the issue have ruled that continued hunting is not per se inconsistent with the creation of a National forest, at least if there is no active logging occurring in it. ${ }^{126}$ Creation of a National Park, on the other hand, does terminate the "unoccupied" status of the land as continued hunting would be inconsistent with one of the major purpose of a National Park. ${ }^{127}$ The different treatment between National Forest and National Park adopted by most courts that have considered this issue seems fair and rational.

\section{PART IV: A Cautionary Tale: State taxation in Indian Country and the level playing field principle.}

The foundational principle here is that States used to have no jurisdiction whatsoever inside Indian Country. ${ }^{128}$ However, 127 years after first denying states any kind of jurisdiction, the Court formulated a new test in its 1959 decision in Williams $v$.

\footnotetext{
${ }^{123} 526$ U.S. 172 (1999).

${ }^{124}$ It has to be noted that the Repsis court also held that even if the treaty right survived admission of Montana in the Union, the lands were no longer unoccupied since they were now part of a National Forrest.

${ }^{125}$ Even if the Tribe wins on this point, the State could still argue on remand that the State's hunting restrictions were necessary for the purpose of conservation and were not discriminatory against the Crow tribal members.

${ }^{126}$ Confederated Tribes of Umatilla Indian Reservation v. Maison, 262 F. Supp. 871, 873 (D. Or. 1966); State v. Tinno, 497 P.2d 1386, 1391 (1972); State v. Arthur, 261 P.2d 135, 141 (1953); State v. Buchanan, 978 P.2d 1070, 1082 (1999), State v. Wallahee, 255 P. 94 (1927).

${ }^{127}$ U.S. v. Hicks, 587 F. Supp. 1162, 1165-66 (Olympic National Park), U.S. v. Peterson, 121 F. Supp. 2d 1309 (2000) (creation of national park abrogated treaty hunting rights), Ward v. Race Horse, 163 U.S. 504, 510, 16 S. Ct. 1076, 41 L. Ed. 244 (1896) (suggesting that Yellowstone National Park is not "unoccupied"). See Holt, Can Indians Hunt in National Parks? Determinable Indian Treaty Rights and United States v. Hicks, 16 Envtl. L. 207 (1986).

${ }^{128}$ Worcester v. Georgia, 31 U.S. 350 (1832).
} 
Lee, ${ }^{129}$ when it stated "[e]ssentially, absent governing Acts of Congress, the question has always been whether the state actions infringed on the right of reservation Indians to make their own laws and be ruled by them." ${ }^{130}$ Although the Court stated that "the question has always been" whether state action infringed on tribal self-government, this was really a novel way to phrase the question. Until then, the Court had only allowed states to assume jurisdiction in three types of situation: First, criminal jurisdiction over non-Indians who had committed crimes against other non-Indians inside Indian reservations. ${ }^{131}$ Second, the Court had allowed reservation Indians to sue non-Indians in state courts. ${ }^{132}$ Third, the Court had also allowed state taxation of non-Indian property inside Indian reservations when such taxation would not interfere with treaty rights possessed by Indians. ${ }^{133}$

The issue in Williams was not about the reach of state taxing power but whether a non-Indian could sue a tribal member residing on the Navajo reservation in a state court to collect on a debt the tribal member had incurred while on the reservation. Having laid down the test described above, the Supreme Court denied the state court jurisdiction because "There can be no doubt that to allow the exercise of state jurisdiction here would undermine the authority of tribal courts over Reservation affairs and hence would infringe on the right of Indians to govern themselves."134 That test became known as the "infringement" test. In 1973, however, the Court appeared to adopt a new test when it stated

The trend has been away from the idea of inherent Indian sovereignty as a bar to state jurisdiction, and toward the reliance on federal preemption. The modern cases thus tend to avoid reliance on platonic notion of Indian sovereignty and to look instead at the applicable treaties and statutes which defines the limits of state power. ${ }^{135}$

Although at first, it seemed that this new "Indian preemption" test was moving away from the search for a level playing field and towards a search for congressional intent, the Court veered back toward a balancing of the interest test when it stated that the Indian preemption inquiry

is not dependent on mechanical or absolute conceptions of state or tribal sovereignty, but has called for a particularized inquiry into the nature of the state, federal and tribal interests at stake, an inquiry designed to determine whether, in the specific context, the exercise of state authority would violate federal law. ${ }^{136}$

\footnotetext{
${ }^{129} 358$ U.S. 217 (1959).

130 Id., at 220 .

${ }^{131}$ U.S. v. McBratney, 104 U.S. 621 (1881), New York ex. rel. Ray v. Martin, 326 U.S. 496 (1946).

132 U.S. v. Candelaria, 272 U.S. 432 (1926), Felix v. Patrick 145 U.S. 317 (1892).

${ }^{133}$ Utah \& Northern Railway v. Fisher, 116 U.S. 28 (1885), Thomas v. Gay, 169 U.S. 264 (1898).

134358 U.S. 217 , at 223.

${ }^{135}$ McClanahan v. State Tax Commission of Arizona, 411 U.S. 164, 172 (1973).

${ }^{136}$ White Mountain Apache Tribe v. Bracker, 448 U.S. 136 (1980).
} 
Eventually, the infringement and the Indian preemption tests merged into one flexible balancing inquiry. Thus, in New Mexico v. Mescalero Apache Tribe, ${ }^{137}$ the Court declared "State jurisdiction is preempted by the operation of federal law if it interferes or is incompatible with federal and tribal interests reflected in federal law, unless the State interests at stake are sufficient to justify the assertion of State authority." 138 In a later case, Justice Ginsburg explained the value of a balancing test for reaching a level playing field in this area of the law

Balancing tests have been criticized as rudderless, affording insufficient guidance to decisionmakers. Pointed as the criticism may be, one must ask, as in life's choices generally, what is the alternative. The principle of tribal self-government, grounded in notions of inherent sovereignty and in congressional policies, seeks an accommodation between the interests of the Tribes, and the Federal Government, on the one hand, and those of the State, on the other. No "bright line" test is capable of achieving such an accommodation with respect to state taxes formally imposed on non-Indians, but impacting on-reservation ventures. ${ }^{139}$

Generally speaking, the Court has highlighted four essential factors in determining whether state law has been preempted under this balancing test. Weighing in favor of tribal interests and therefore indicating preemption are first, whether there is a "backdrop" of tribal sovereignty and immunity from state regulation in the area being regulated, ${ }^{140}$ and secondly, whether the activity the state wants to regulate involves a value generated on the reservation by activities involving the Tribe. ${ }^{141}$ On the other hand, state interests are more important when the activity occurring on the reservation could have serious off-reservation effects. ${ }^{142}$ Finally, the Court has stated that " $(t)$ he exercise of state authority which imposes additional burdens on a tribal enterprise must ordinarily be justified by functions or services performed by the State in connection with the on-reservation activity." 143

The formulation and application of the Indian preemption test was initially heavily influenced by Justice Thurgood Marshall. The use of the balancing test in the opinions where he was in the majority reflected a legitimate effort to find a level playing field between the tribal interests on one hand and state interests on the other. ${ }^{144}$ It is

\footnotetext{
137462 U.S. 324 (1980).

138 Id., at 334 .

139 Wagnon v. Prairie Band Potawatomi Nation, 546 U.S. 95, at 124-125 (1999) (Ginsburg dissenting.)

140 See Rice v. Rehner, 463 U.S. 713, 725 (1983)(allowing state liquor regulations on the reservations because there was no backdrop tribal immunity from state jurisdiction in this regulatory area.)

141 See California v. Cabazon Band of Mission Indians, 480 U.S. 202 (1987)(Denying state jurisdiction over Indian gaming and finding that the tribes were not merely marketing an exemption from state law but had "built modern facilities which provide recreational opportunities and ancillary services to their patrons." Id., at 219.)

142 See Rice v. Rehner, 463 U.S. 713, (finding that liquor sales on the reservations do have a spillover effect outside the reservations) Id., at 719 .

${ }^{143}$ New Mexico v. Mescalero Apache Tribe, 462 U.S. 324, at 334 (1983).

${ }^{144}$ See for instance, McClanahan v. Arizona State Tax Commission, 411 U.S. 164 (1973), White Mountain Apache Tribe v. Bracker, 448 U.S. 136 (1980), Central Machinery v. Arizona Tax Commission,
} 
important to realize, however, that Justice Rehnquist never believed in a balancing test. In a concurrent and dissenting opinion in Washington $v$. Confederated Tribes he objected to any balancing stating "I see no need for this Court to balance the state and tribal interests in enacting particular forms of taxation in order to determine their validity. Absent discrimination, the question is only one of congressional intent. Either Congress intended to pre-empt the state taxing authority or it did not.."145 In that same 1980 opinion, Justice Rehnquist gave a meaningful hint on what was preoccupying him. The case was about the power of the state of Washington to tax non-members buying cigarettes from tribal retailers on the reservation. In upholding the state taxing authority, Justice Rehnquist stated

It is painfully apparent that the value marketed by the smokeshops to persons coming from outside is not generated on the reservations by activities in which the Tribes have a significant interest. What the smokeshops offer these customers, and what is not available elsewhere, is solely an exemption from state taxation... We do not believe that principles of federal Indian law, whether stated in terms of preemption, tribal self-government, or otherwise, authorize Indian tribes thus to market an exemption from state taxation to persons who would normally do their business elsewhere. ${ }^{146}$

At first, this language seems to fit into the level playing field principle between states and tribes. However, it is far from it. If it were, Indian tribes should be able to force the states to collect tribal tax from off reservation vendors selling to people residing on Indian reservations. Secondly, this "marketing an exemption" principle has no application to state residents purchasing goods outside their own state of residence. People living in the Maryland and Virginia suburbs routinely buy their liquor in the District of Columbia because it is cheaper there. Many people residing in the State of Washington buy expensive goods in Oregon because Oregon has no sales tax. The "marketing an exemption" principle is not about levelling the playing field. If anything, it is about un-leveling the field to subrogate tribal interests to the interests of the states.

Rehnquist may not have wanted the tribes to benefit from what he perceived to be an unfair advantage but in allowing state taxation in that case, the Court gave a disincentive for anyone but the tribe's members to buy cigarettes on the reservations. The concurring and dissenting opinion of Justice Stewart made a valid point when it stated

448 U.S. 160 (1980), Ramah Navajo School Board, 458 U.S. 832, Mescalero Apache Tribe, 462 U.S. 324, and California v. Cabazon Band of Mission Indians, 480 U.S. 202 (1987).

${ }^{145}$ Washington v. Confederated Tribes of Colville Indian Reservation, 447 U.S. 134, 161 (1979).

${ }^{146}$ Id., at 155. The Court added: "The Tribes assert the power to create such exemptions by imposing their own taxes or otherwise earning revenues by participating in the reservation enterprises. If this assertion was accepted, the Tribes could impose a nominal tax and open chains of discount stores at reservation borders, selling goods of all descriptions at deep discounts and drawing custom from surrounding areas." Id. 
when a State and an Indian tribe tax in a functionally identical manner the same on-reservation sales to nontribal members, it is my view that congressional policy conjoined with the Indian Commerce Clause requires the State to credit against its own tax the amount of the tribe's tax... it permits the tribe to share with the State in the tax revenues from cigarette sales, without at the same time placing the tribe's federally encouraged enterprises at a competitive disadvantage compared to similarly situated off-reservation businesses. ${ }^{147}$

Unfortunately for the tribes, although Justice Marshall's version of the Indian preemption inquiry initially carried the day, Rehnquist's version of that inquiry seemed to have prevailed in more recent times. In the last thirty years, there has been many cases allowing states taxation in Indian Country. ${ }^{148}$ While the Court used a balancing of the interest test to determine the extent of state taxation of non-members up to 1989, it pretty much abandoned any attempt at real balancing in Cotton Petroleum Corp. v. New Mexico. ${ }^{149}$ The issue in Cotton Petroleum was whether the state could impose a severance tax on oil and gas produced by a non-Indian corporation whose income was generated from land it was leasing from the Tribe within the Mescalero Apache Indian reservation. The Court held that the state tax was not preempted. Founding no "backdrop of tribal sovereignty" in this area of the law, the Court took the position that there was no presumption in favor of preemption. Instead, the Court asked whether subsequent legislation could be construed as preempting such state taxation and found none. In dissent, Justice Blackmun thought that the majority had given up on a true balancing of the interests, and stated

Instead of engaging in a careful examination of state, tribal and federal interests . .. the majority has adopted the principle of "the inexorable zero". . . [u]nder the majority's approach, there is no pre-emption unless the States are entirely excluded from a sphere of activity and provide no services to the Indians or to the lessees they seek to tax. ${ }^{150}$

Furthermore, the dissent also noted that in finding that state taxation here would not impose any economic burden on the tribe, the Court blinded itself to the economics of oil and gas production. As stated by the Dissent: "The fact that the Jicarilla Apache have seen fit to impose their own taxes renders the threat to tribal interests which is always inherent in state taxation all the more apparent. The market can bear only so much taxation, and it is inevitable that a point will be reached at which the State's taxes will impose a ceiling on tribal tax revenues." 151

\footnotetext{
${ }^{147}$ Id, at 175 ,

148 See Cotton Petroleum v. New Mexico, 490 U.S. 163 (1989), Department of Taxation v. Milhelm, 512 U.S. 679 (1994), Montana v. Crow Tribe, 523 U.S. 696 (1998), Arizona Department of Revenue v. Blaze Construction, 526 U.S. 32 (1999), City of Sherrill v. Oneida Indian Nation, 544 U.S. 197 (2005), Wagnon v. Prairie Band Potawatomi Nation, 546 U.S. 95 (2005), County of Yakima v, Confederated Tribes, 502 U.S. 251 (1992), and Cass County v. Leech Lake Band, 524 U.S. 103 (1998).

149490 U.S. 163 (1988).

150 Id., at 204.

151 Id., at 209-10. See also F. Michael Willis, The Power to Tax Economic Activity in Indian Country, 28SPG Nat. Resources \& Env't 8 (2016), at 10-11.
} 
After Cotton Petroleum, when the facts guiding the Indian preemption balancing inquiry seemed to disfavor state taxation, the Court found other ways to allow state taxation. For instance in Blaze Construction, ${ }^{152}$ the court refused to use the Indian preemption doctrine because the non-Indian contractor in charge of a road improvement project was working pursuant to a contract with the federal government. Why should the fact that a contract is with the federal government matters when it comes to the application of the Indian preemption doctrine? The Court had only this to say: "The need to avoid litigation and to ensure efficient tax administration counsels in favor of a brightline standard for taxation of federal contracts, regardless of whether the contracted-for activity takes place on Indian reservations. ${ }^{153}$

Another case where the Court refused to use the balancing of the interest test was Wagnon v. Prairie Band Potawatomi Nation. ${ }^{154}$ The issue in Wagnon was whether the State of Kansas could impose an excise tax on fuel sold by a non-Indian distributor to the Prairie Band of Potawatomi Nation. The Court of Appeals for the Tenth Circuit had ruled against the state tax using the traditional balancing preemption test. ${ }^{155}$ The Supreme Court reversed, holding that the state taxing statute meant to tax the receipt of the fuel by the first distributor and not its subsequent sale to the tribe. Therefore, the balancing test was not applicable because the tax incurred by the non-Indian distributor occurred off the reservation. ${ }^{156}$

In her dissent, Justice Ginsburg noted that although the tax was formally imposed on the non-Indian distributor, in reality, the tax burdened reservation activities. According to her, the tax should have been considered as having taken place on the Indian reservation because under the applicable statute, "[t]o whom and where the distributor sells are the criteria that determine the 'transactions' on which '[n]o tax is ... imposed, and correspondingly the transaction on which the tax is imposed."' 157 Another instance where the Court showed its blindness to the economic realities on the ground occurred when Justice Thomas, writing for the majority, asserted that the tribe's "[d]ecision to impose a tax should have no effect on its net revenues from the operation of the station." ${ }^{158}$ As Justice Ginsburg noted in dissent: "[a]s a practical matter, however, the two tolls cannot coexist." 159

\footnotetext{
${ }^{152}$ Arizona Dept. of Revenue v. Blaze Const. Co., Inc., 526 U.S. 32 (1999).

153 Id., at 37-38.

${ }^{154} 546$ U.S. $95(2005)$

${ }^{155} 379$ F.3d $979\left(10^{\text {th }}\right.$ Cir. 2004).

${ }^{156}$ The Court revealed its antagonism towards the balancing preemption test when it stated: "The application of the interest-balancing test to the Kansas motor fuel tax is not only inconsistent with the special geographic sovereignty concerns that gave rise to that test, but also with our efforts to establish a 'bright line standard[s]' in the context of tax administration." 546 U.S. at 113.

${ }^{157} 546$ U.S. at $123-124$.

${ }^{158}$ Id., at 114 .

${ }^{159}$ Id., at 116.
} 
In City of Sherrill v. Oneida Indian Nation, ${ }^{160}$ a case decided the same year as Wagnon, Justice Ginsburg was not as sympathetic to the tribe. The issue there was whether the City could tax property the Oneida Indian Nation had recently bought. The tribe was arguing that the property was not taxable because it was located within the tribe's ancestral treaty reservation. The city was arguing that the area where the Tribe had recently acquired its land was no longer within the exterior border of the reservation. The Court, per Justice Ginsburg, disagreed and upheld the right of the City to tax tribal property. Refusing to answer whether the properties were within the ancestral tribal treaty reservation, the Court instead grounded its holding in the three equitable doctrines of laches, acquiescence, and impossibility. ${ }^{161}$

The Court also added some confusing language that allowed lower courts to greatly expand on an already, to put it kindly, innovative application of the law. First, it fashioned a new principle under which Indian tribes cannot invoke their sovereign powers if it would be disruptive of the settled and justifiable expectations of state entities. ${ }^{162}$ The Court also added "When a party belatedly asserts a right to present and future sovereign control over territory, longstanding observances and settled expectations are prime considerations. There is no dispute that it has been two centuries since the Oneidas last exercised regulatory control over the properties here or held them free from local taxation." 163

Later in the opinion, Justice Ginsburg implicitly acknowledged that lack of limiting principles were at play in the Court's decision. Thus, she stated "If OIN may unilaterally reassert sovereign control and remove these parcels from the local tax rolls, little would prevent the Tribe from initiating a new generation of litigation to free the parcels from local zoning or other regulatory controls that protect all landowners in the area."164

Although Justice Ginsburg asserted that "the question of damages for the Tribe's ancient dispossession is not at issue in this case, and we therefore do not disturb our holding in Oneida II,"165 lower courts have interpreted City of Sherrill as preventing any remedies, ${ }^{166}$ including monetary damages, that would be disruptive of the long standing

\footnotetext{
${ }^{160} 544$ U.S. 197 (2005).

${ }^{161}$ As stated by the Court, "the distance from 1805 to the present day, the Oneidas' long delay in seeking equitable relief against New York or its local units, and developments in the city of Sherrill spanning several generations, evoke the doctrines of laches, acquiescence, and impossibility, and render inequitable the piecemeal shift in governance this suit seeks unilaterally to initiate." 544 U.S. 197, 221.

${ }^{162}$ As stated by the Court "This Court has observed in the different, but related, context of the diminishment of an Indian reservation that "[t]he longstanding assumption of jurisdiction by the State over an area that is over $90 \%$ non-Indian, both in population and in land use," may create "justifiable expectations." ... Similar justifiable expectations, grounded in two centuries of New York's exercise of regulatory jurisdiction, until recently uncontested by OIN, merit heavy weight here." Id., at 215-16.

${ }^{163} 544$ U.S. $197,218-19$.

${ }^{164}$ Id., at 220.

${ }^{165}$ Id., at 221

${ }^{166}$ See Joseph William Singer, Indian Title: Unravelling the Racial Context of Property Rights, 10 Alb. Gov't L Rev. 1, 43 (2017).
} 
expectations of non-Indians. ${ }^{167}$ Also forbidden would be any tribal claim premised on the Oneidas' assertion of a valid title to their original reservation. ${ }^{168}$

I am willing to agree that the actions of the Oneida Indian Nation in City of Sherrill disrupted the settled expectations of the taxing governmental entities. However, if that is the case, a fair level playing field between the tribes and the states would call for a prohibition on the states, counties, and towns from disrupting the justifiable and settled expectations of Indian tribes. Yet none of that was ever mentioned in Alaska v. Native Village of Venetie when years after passage of Alaska Native Claims Settlement Act (ANCSA), the Court held that tribally owned land was not Indian country and, and therefore, the tribe had no sovereign power to tax non-members working on those lands. ${ }^{169}$ The same applies to the situation in Carcieri v. Salazar, ${ }^{170}$ where 75 years after enactment of the Indian Reorganization Act (IRA), ${ }^{171}$ the Court discovered that tribes not under federal jurisdiction as of 1934, could not petition the federal government to take land into trust for them. Not to mention older decisions like Tee-hit-ton Indians $v$. United States which held that Alaskan Native tribes never had recognized title to lands they thought was theirs since time immemorial. ${ }^{172}$ And this is just the proverbial tip of the iceberg. One could write a book about all the Supreme Court cases that have upset the settled and justifiable expectations of Indian tribes throughout history. ${ }^{173}$

\section{CONCLUSION:}

The Indian preemption doctrine started out as a mean of balancing conflicting tribal and state interests but was, in the long run, hijacked by Justices such as Chief Justice Rehnquist, who did not believe in any level playing field or, for that matter, in tribal sovereignty. What happened to the Indian preemption doctrine should serve as a cautionary tale for all cases where the Court attempts to use limiting principles or reach level playing fields.

Every legal doctrine or principle of law has policy goals behind it. Sometime, courts officially delineate the policies underlying the principle of law or doctrine on which their decisions purportedly rest. Other times, there are unstated background norms and goals not officially mentioned by the Court that nevertheless play a crucial role in the decisions. This article has argued that when it comes to off-reservation tribal sovereign

\footnotetext{
${ }^{167}$ Cayuga Indian Nation v. Pataki, 413 F.3d 266 (2d Cir. 2005). See also, Kathryn E. Fort, The New Laches: Creating Title Where None Existed, 16 Geo. Mason L. Rev 357 (2009).

${ }^{168}$ Oneida Indian Nation v. County of Oneida, 617 F.3d 114, 135 (2d Cir. 2010), See also StockbridgeMunsee Community v. New York, 756 F.3d 163, 165 (2d Cir. 2014)(stating "It is now well established that Indian land claims asserted generations after an alleged dispossession are inherently disruptive of state and local governance and the settled expectations of current landowners, and are subject to dismissal on the basis of laches, acquiescence, and impossibility."

${ }^{169} 522$ U.S. $520(1998)$.

${ }^{170} 555$ U.S. 379 (2009).

${ }^{171}$ Act of June 18, 1934, 48 Stat 984.

${ }^{172} 348$ U.S. 272 (1955).

${ }^{173}$ See for instance, Walter Echo-Hawk, In the Courts of the Conqueror: The Ten Worst Indian Law Cases Ever Decided.
} 
immunity and off reservation treaty rights, the Court has been looking for limiting principles purporting to establish level playing fields between the tribes and the states. Whether a level playing field has been achieved, however, is in the eyes of the beholder as it involves a subjective judgment. It is also a goal that may not be truly reachable because of the different constitutional status of Tribes and States. As the areas of tribal jurisdiction over non-members and state taxation on Indian reservations have shown, limiting principles can easily be manipulated against tribal sovereign interests. One can only hope that the same thing does not happen to the areas of tribal sovereign immunity and tribal treaty rights. 